\title{
Am I Motivated? A Look at the Motivation Styles, Symptoms and Working Conditions that Best Motivate Human Resource Practitioners in Jamaica
}

\author{
Cerease Nevins-Bennett \\ School of Business and Entrepreneurial Studies, Excelsior Community College, Kingston, Jamaica \\ Email: Cereasenevins@hotmail.co.uk
}

Received October 7, 2013; revised November 8, 2013; accepted November 16, 2013

Copyright (C) 2013 Cerease Nevins-Bennett. This is an open access article distributed under the Creative Commons Attribution License, which permits unrestricted use, distribution, and reproduction in any medium, provided the original work is properly cited. In accordance of the Creative Commons Attribution License all Copyrights (C) 2013 are reserved for SCIRP and the owner of the intellectual property Cerease Nevins-Bennett. All Copyright (C) 2013 are guarded by law and by SCIRP as a guardian.

\begin{abstract}
Human Resource Practitioners, like any other employees within organizations having different motivation styles, are faced with various motivational problems, and are exposed to different working conditions that best motivate them. The environment and factors greatly influence the motivational levels of these practitioners and thus job satisfaction and engagement are affected. This paper outlines the motivation problems experienced by three persons in their work environment and gives suggestions as to the strategies necessary to deal with them. The Pritchard Motivation Symptoms Questionnaire, the Conner Motivation Style Assessment and the Spitzer Motivation Self Assessment Questionnaire were used in the study. Results show that goal orientated and learning oriented motivation styles are best practiced by participants neglecting the relationship motivation style. These Participants were either highly motivated or had experienced some motivation problems. They had major desires for power, achievement, ownership, and competence. Inter-item correlation revealed a statistically significant relationship between desires for activity, competence, power and achievement, which were highly correlated.
\end{abstract}

Keywords: Work Motivation; Motivation Styles; Motivation Symptoms; Intrinsic Motivation and Extrinsic Motivation

\section{Introduction}

Work motivation is a topic that has been the centre of great debate and controversy over the past years; many scholars have taken it seriously and written numerous articles and books on the topic. However it is a difficult concept to explain since different writers have used various terms and phrases to operationalize work motivation.

According to Moyniham et al. [1], "work motivation has been operationalized in the literature as job satisfaction, organizational commitment, and job involvement which are all dependent variables". It has also been operationalized as job characteristics and employee engagement [1]. Nevertheless, work motivation may be defined as "a set of energetic force that originate both within as well as beyond an individual being, to initiate work-related behavior, and to determine its form, direction, intensity, and duration", Pinder [2].
Great organizations are built on the inherent value of their human resources as motivated and committed employees almost always allow an organization to grow faster than similar competitive organizations, Mohsan et al. [3]. Thus, employees can be motivated at work both intrinsically and extrinsically.

Employee motivation may be a result of job satisfaction, job involvement, and job commitment. Job satisfaction has been defined as the "pleasurable or positive emotional state resulting from the appraisal of one's job or job experience", Locke et al. [4]. Employee commitment indicates the sense of loyalty and obligation the employee holds toward the organization, Allen et al. [5]; and organizational commitment helps to motivate individuals to pursue collective goals rather than individual outcomes [5].

For the Human Resource practitioners, job satisfaction contains positive influences on the performance of the employees as it enhances job involvement, higher per- 
formance, and makes them feel more satisfied and committed to the organization, Saleem [6] despite of the many motivational problems they experience. The practitioners differ in their motivation styles, symptoms and the environment most conducive to their motivational levels.

This paper outlines the motivation problems experienced by three persons in their work environment and gives suggestions related to the strategies necessary to deal with them. Three motivation assessment measures were used to assess their levels of motivation within the organization from which data was collected to generate this report. These assessments are the Pritchard Motivation Symptoms Questionnaire, the Conner Motivation Style Assessment and the Spitzer Motivation Self Assessment Questionnaire.

\section{Methodology}

\subsection{Population and Sampling}

Three human resource practitioners were selected from different organizations representing the educational industry, the pharmaceutical industry, and the service industry. The participants were selected by a purposive sampling method and reflected employees from different socioeconomic background, industry and demographics within their respective organizations.

A mixed method approach was used to analyze the effects of participant's motivation styles, motivation symptoms and the working condition that is perceived to motivate them on their motivation levels.

\subsection{Data Collection Method}

The data collection methods used were survey (questionnaires) and interviews. Three questionnaires were administered to each participant assessing their motivation styles, symptoms and the working condition that motivates them.

Thirty minutes (30 minutes) in-depth interviews were conducted with all three employees (separately) about their motivation issues. A content analysis was then conducted for the interview data based on preconceived and emerging themes. The findings were then interpreted for each person followed by strategies to deal with the problems arising.

\subsection{Instrumentation}

The motivation symptoms questionnaire, the Spritzer's motivation assessment and the Connor motivation style questionnaire were the instruments used to collect data for this study. All three instruments were administered to the participants to determine their motivation levels.
The Pritchard motivation symptoms questionnaire was used to assess whether or not a participant or person working in their immediate work groups had motivation problems. The questionnaire consists of 21 statements ranked on a scale of 1 to 3 with 1 being "rarely or never", 2 being "sometimes" and 3 being "often". The rankings for the three categories were added independently and compared against a range of scores. Scores falling within the 21 - 30 range means "green light" and signifies that the participant being assessed is highly motivated; 31 45 is the yellow light range which means that participant have some motivation problems; and 46 - 63 is the red light range which means that they have serious motivation problems.

The Spritzer's motivation assessment questionnaire is a self assessment questionnaire that is used to determine the working condition that best motivates an employee. It consists of 32 statements which are ranked on a scale of 1 to 4 . From 1 being "not very important" to 4 being "very important". Scores are then transferred to a table, summed and divided into 8 categories A to H. Category A consists of scores obtained from items 1,9,17 and 25) labelled "Desire for Activity"; Category B is the "Desire for Ownership" (items 2, 10, 18 and 26); and categories $\mathrm{C}-\mathrm{H}$ are Desires for power, affiliation, competence, achievement, recognition and meaning respectively. The two categories which participants scored the highest were identified and interpreted.

The Conner motivation style questionnaire was used to assess how participants were motivated to learn. The questionnaire consisted of 10 stem items that were matched individually against statements placed into three columns that best characterized the participants. Columns 1 to 3 were labelled goal, relationship and learning respectively to reflect the three motivation styles according to Conner. The numbers of selected responses were totalled in each category and the highest score was used to determine the participant's primary motivation style. The second highest score reflected the participant's secondary motivation style.

\subsection{Data Analysis}

Information from the questionnaires were analyzed using the Statistical Package for the Social Sciences (SPSS 16.0), while the interview data were analyzed using content analysis. The researcher used inter-item correlation to determine the relationship between the eight desirable working conditions that best motivated an employee.

\section{Case Profiles}

\subsection{Laketa Davis}

Laketa is a 30-year-old Human Resource Administrative Assistance at Sewell Jamaica Limited, a manufacturing 
entity. She has been employed there for five years in the current position and is required to provide office-based administrative support to the Sewell Human Resource Directors. The job description of the Administrative Assistant includes coordinating and scheduling day-to-day activities including meeting and training programmes for employees; room bookings for training and meetings of staff, conference registration; research and compile data for special projects; develop and maintain print documents and files of employees. She also provides office services by implementing administrative systems, procedures, and policies; and monitoring administrative projects; contribute to the yearly report writing; attend meetings and or focus group discussions and prepare minutes and generating mailings, just to name a few.

\subsection{Samantha Blackwood}

Samantha is a 37-year-old Training and Development Officer who has been employed at a Teachers College for eleven years and reports to the Director of Human Resource Development and Administration. She currently trains staff in the areas of manpower management, human relation skills, and customer service. The job descriptions of the Training and Development Officer are to conduct appraisals; evaluate training and development programmes; devise individual learning plans; and ensuring that statutory training requirements are met. Other responsibilities include researching new human resource and workforce technologies, research new management trends; and implement budgetary systems and controls for the department.

\subsection{Noel Davis}

Noel is a 26-year-old male Human Resource Officer at a hospital, and has been in the position for three years. His key responsibility is to provide advice and assistance to staff, coordinate the recruitment process and aid in the selection process of new employees. His main responsebilities are to ensure that proper job descriptions of staff are prepared and in files, monitor daily attendance of employees, provide advice and recommendations on disciplinary actions; and filing of employee records.

\section{Report}

The motivation assessment, style, and symptom questionnaires were assessed and Table 1 was generated. Based on the results, two out of three participants had the disposition to achieve through direct and obvious routes (goal orientation) with secondary propensity to search for knowledge. The desire for achievement was strongest among Noel and Samantha with Laketa having a strong desire for ownership.
Table 1. Findings of the Motivation assessment, style, and symptoms questionnaires for the three Human Resource Practitioners.

\begin{tabular}{|c|c|c|c|}
\hline & Laketa & Samantha & Noel \\
\hline $\begin{array}{c}\text { Motivation } \\
\text { Styles } \\
\text { Primary } \\
\text { Secondary }\end{array}$ & $\begin{array}{l}\text { Goal oriented } \\
\text { Learning } \\
\text { Oriented }\end{array}$ & $\begin{array}{l}\text { Goal Oriented } \\
\text { Learning } \\
\text { oriented }\end{array}$ & $\begin{array}{c}\text { Learning } \\
\text { oriented } \\
\text { Goal oriented }\end{array}$ \\
\hline $\begin{array}{c}\text { Motivation } \\
\text { Symptoms } \\
\text { Scores obtained }\end{array}$ & 40 & 30 & 27 \\
\hline $\begin{array}{l}\text { Category } \\
\text { Meaning }\end{array}$ & $\begin{array}{c}31-45 \\
\text { (Yellow light) } \\
\text { Motivation } \\
\text { problems exists }\end{array}$ & $\begin{array}{c}31-45 \\
\text { (Yellow light) } \\
\text { Motivation } \\
\text { problems exists }\end{array}$ & $\begin{array}{c}21-30 \\
\text { (Green light) } \\
\text { Highly motivated }\end{array}$ \\
\hline $\begin{array}{l}\text { Conditions that } \\
\text { best motivates } \\
\text { Highest Desires }\end{array}$ & "Ownership" & "Achievement" & $\begin{array}{c}\text { "Power" } \\
\text { "Ownership" } \\
\text { "Affiliation", } \\
\text { "Competence" } \\
\text { "Achievement" }\end{array}$ \\
\hline $\begin{array}{l}\text { Lowest } \\
\text { Desires }\end{array}$ & $\begin{array}{l}\text { "Competence" } \\
\text { "Achievement" } \\
\text { "Recognition" } \\
\text { "Meaning" }\end{array}$ & $\begin{array}{l}\text { "Ownership" } \\
\text { "Meaning", }\end{array}$ & $\begin{array}{l}\text { "Activity" } \\
\text { "Meaning" }\end{array}$ \\
\hline
\end{tabular}

\subsection{Respondent \#1-Laketa Davis}

\subsubsection{Content Analysis of Interview}

When asked what success meant to her career, Laketa responded by stating that success means getting a good salary, perquisites, having autonomy, and being promoted.

When asked what goals, including career goals, she has set for her life, she responded by saying "I want to return to university and finish my degree in Business Administration, because an associate degree is not allowing me to earn as much money as I want and I have bills to pay, in fact without that degree I will never be promoted".

When asked about staying motivated despite failure, she shook her head and stated "that's a hard question, in this organization it's difficult to stay motivated because of the organizational culture, and I usually try not to think about the failure and just move on hoping not to make the same mistake again".

\subsubsection{Interpretation}

Based on the questionnaires and the interview it is clear that Laketa is a goal oriented individual with motivation problems. Having a high desire for ownership, she is most motivated to work in an environment where she feels apart of the organization, have a stake in its success, able to make choices at work, and have a feeling of responsibility for the work she does.

Laketa's secondary desires for competence, achievement, recognition and meaning gives her the desires to work in an organization where she is given learning 
opportunities; is allowed to set goals for herself and encouraged to improve; be shown appreciation; feel rewarded for success; and where she can relate her objectives to the bigger picture and get a sense of meaning from her job.

As an Administrative Assistant in the Human Resource Department, the job allows for some level of control, coordination, organization of activities, research and compiling data that fits Laketa's style, level and desires of motivation perfectly; however, other extraneous factors are playing a role on her level of motivation.

\subsubsection{Recommendations}

As a goal oriented person who has strong needs for achievement and competence, Laketa should seek employment elsewhere because the motivation symptoms questionnaire revealed that she has little loyalty to the unit or organization. Job satisfaction affects job involvement and thus job performance. If she is uncomfortable in her work environment, makes the least possible efforts at work, and frequently reports stress and fatigue then it is highly recommended that she receives counseling or seek a job elsewhere. Counselling will help to unveil some the factors that are affecting her motivation level and suggestions will be given to deal with those problems.

\subsection{Respondent \#2-Samantha Blackwood}

\subsubsection{Content Analysis of Interview}

When asked what success meant to her career, Samantha responded by stating that success means doing her job to the best of her ability and getting quality results. She stated that "my role as a training and development officer is not an easy one but I feel a sense of accomplishment when I can depart knowledge and employees learn".

When asked what goals, including career goals, she has set for her life; she responded by saying "well I have every intention to become a better training officer. I believe if I enroll in a postgraduate degree in education, not only would I become a better trainer but also a facilitator and program evaluator". She stated that currently she is not comfortable as a trainer; she believes that a degree in Human Resource Management provides her with sufficient knowledge to build her craft, but a postgraduate degree in education will be even more beneficial to her intellectual capabilities.

When asked about staying motivated despite failure, she stated "It is hard to stay motivated at times, but I receive strong social support from friends and family members and it helps me to keep strong in times of disappointments and failures".

\subsubsection{Interpretation}

Samantha is goal orientated with some motivational problems. Her desires for achievement, ownership and meaning drives her to work in an organizational environment where she feels motivated to succeed at her work; has a stake in its success; and is able to relate her objectives to the bigger picture and get a sense of meaning from her job.

\subsubsection{Recommendations}

Samantha has some motivation problems which need to be addressed. She is dissatisfied with her role as a training and development officer and has a strong drive for achievement at the organizational and interpersonal levels. To move forward Samantha needs to work hard and overcome the fear of change by focusing on the certainties and possibilities and not the uncertainties. She needs to move forward with her career goals and aspirations.

\subsection{Respondent \#3-Noel}

\subsubsection{Content Analysis of Interview}

When asked what does success means to his career, he responded by stating that success means having job security and stability, being promoted, and being able to contribute to the bottom line of the organization.

When asked what goals, including career goals, he has set for his life, he responded by saying "I want to further my studies in the field of Human Resource Development to become a better practitioner and self actualize-I want to "call the shots" and make key decisions within the organization, but it's only a matter of time".

When asked about staying motivated despite failure, he stated that he "usually draws on past experiences or accomplishments" and this increases his self-efficacy for accomplishing the task at hand. He stated that he also tries "not to compare his successes or failures with that of others, but to remember that each person is different". This speaks to the fact that Noel has experienced some amount of intrinsic motivation, one which keeps him focused on achieving his goals despite challenges, and one which encourages him to press forward despite the fact that he is not promoted at a faster rate.

\subsubsection{Interpretation}

Noel is learning oriented, highly motivated, and works well in an environment that gives him power, ownership, affiliation, competence and achievement. Noel's goal orientation style is consistent with his motivation for a achievement, which was reported as being one of his secondary motivation styles on the Motivation style assessment.

Noel's desire for power, ownership, affiliation, and achievement allows him to operate most efficiently in an organizational environment where he is in control of his own destiny make choices at work; feels apart of the organization and have a stake in its success; given the 
opportunity to socialize, feels motivated and he can succeed at his work; thus he is self-motivated to deliver and achieve. His desires allow him to seek leadership opportunities and feeling of empowerment to make decisions.

Noel works most comfortably in an environment where he uses his hidden strengths; given learning opportunities; and learns through mistakes; set goals for himself; be encourage to improve; feels active and involved, and having meaning from his job.

\subsubsection{Recommendations}

Based on the questionnaires and interview, Noel seemed highly motivated, driven and goal directed. However, there have been problems or factors that affect such thrust to move forward which may affect his level of motivation in the long run. Though the Motivation symptoms questionnaire revealed that he was highly motivated it also revealed that he sometimes had low job satisfaction, sometimes focus on rules rather than the best way to get things done and fail to generate innovative ideas. These problems he said was due to the nature of his work environment. To make improvements in these areas he needs to be given more control over his work, encouraged to use his own initiative and be the generator of new ideas that will move his organization forward and cementing his desires for power.

\section{Pair-Wise Correlation}

When the Spitzer's eight desires were correlated with each other for all three participants, Table 2 was produced. Noticeable results occurred between the desires for activity, competence, achievement, power and meaning.

Desire for Activity was perfectly correlated with desires for competence and achievement and statistically significant. Desire for power was perfectly correlated with the desire for meaning. The desire for competence was perfectly correlated with the desire for achievement.

Cronbach alpha, $\alpha=0.910$ obtained was acceptable and indicates good internal consistency of the items in the scale, but this does not mean that the scale is unidimensional.

\section{Discussion}

The content analysis was done as a means of summarizeing the verbal content of the interview transcriptions and to provide more objective evaluation of the participants. A number of themes emerged from the interviews which were consistent among the three participants such as the need for achievement; the need for a satisfactory working environment; the need to set clear and achievable goals; the need for autonomy; the need for power; the need for competence and relatedness.

\subsection{Need for Achievement}

The need for achievement was strong amongst the three participants because they wanted to succeed at what they did and accomplish greatness.

Because their needs were strong, they were motivated to use appropriate behaviours to satisfy those needs which are usually learned from the culture of the society. Samantha and Noel scored the highest on achievement when the Spitzer motivation self assessment was administered to determine the working conditions that best mo-

Table 2. Correlation of the eight desires of motivation that drives people in the workplace.

\begin{tabular}{|c|c|c|c|c|c|c|c|c|c|c|}
\hline & $\begin{array}{l}\text { Desire for } \\
\text { Activity }\end{array}$ & $\begin{array}{l}\text { Desire for } \\
\text { Ownership }\end{array}$ & $\begin{array}{l}\text { Desire for } \\
\text { Power }\end{array}$ & $\begin{array}{l}\text { Desire for } \\
\text { Affiliation }\end{array}$ & $\begin{array}{l}\text { Desire for } \\
\text { Competence }\end{array}$ & $\begin{array}{c}\text { Desire for } \\
\text { Achievement }\end{array}$ & $\begin{array}{l}\text { Desire for } \\
\text { Recognition }\end{array}$ & $\begin{array}{l}\text { Desire for } \\
\text { meaning }\end{array}$ & Mean & SD \\
\hline $\begin{array}{l}\text { Desire for } \\
\text { Activity }\end{array}$ & 1.00 & & & & & & & & 12.67 & 2.31 \\
\hline $\begin{array}{l}\text { Desire for } \\
\text { Ownership }\end{array}$ & 0.94 & 1.00 & & & & & & & 14.67 & 1.53 \\
\hline $\begin{array}{l}\text { Desire for } \\
\text { Power }\end{array}$ & 0.50 & 0.19 & 1.00 & & & & & & 12.33 & 2.31 \\
\hline $\begin{array}{l}\text { Desire for } \\
\text { Affiliation }\end{array}$ & 0.19 & -0.14 & 0.94 & 1.00 & & & & & 11.67 & 3.06 \\
\hline $\begin{array}{l}\text { Desire for } \\
\text { Competence }\end{array}$ & $1.00^{* *}$ & 0.94 & 0.50 & 0.19 & 1.00 & & & & 13.67 & 2.31 \\
\hline $\begin{array}{c}\text { Desire for } \\
\text { Achievement }\end{array}$ & $1.00^{* *}$ & 0.94 & 0.50 & 0.19 & $1.00^{* *}$ & 1.00 & & & 14.67 & 0.58 \\
\hline $\begin{array}{l}\text { Desire for } \\
\text { Recognition }\end{array}$ & 0.76 & 0.93 & 0.19 & -0.50 & 0.76 & 0.76 & 1.00 & & 13.33 & 1.53 \\
\hline $\begin{array}{l}\text { Desire for } \\
\text { meaning }\end{array}$ & 0.87 & 0.98 & 0.00 & -0.33 & 0.87 & 0.87 & 0.98 & 1.00 & 14.00 & 1.00 \\
\hline
\end{tabular}

**Correlation is significant at the 0.01 level (two tailed). 
tivated them; and based on the interviews conducted it was clear that they were both motivated to achieve moderate goals at all costs.

\subsection{Need for Recognition}

Laketa has a low need for recognition according to the results obtained from the Spitzer motivation self assessment, but the interviews revealed otherwise. A need for recognition is a social need where people feel good when others acknowledge their existence and praise them. Laketa, with a high need for recognition appreciates guidance and support with frequent feedbacks. For Samantha and Noel, the need for recognition was not captured from the questionnaire but from the interview. Noel stated that he likes when his customers are happy and appreciate what he does as well as when they praise him. Samantha commented on the fact that being recognized is good as it builds one's self esteem and confience which will lead to job satisfaction over a period of continuous recognition. Recognition is close to Maslow's need for esteem, and plays to the need for a sense of identity.

\subsection{Need for Relationship}

The need for relationship is associated with McClelland's Need for Affiliation, Spritzer's Desire for Affiliation, Maslow's need for Belonging and plays to the need for a sense of identity within the organization.

The need for affiliation means that people are linked to other people or institutions thus infusing their identities. This will allow the practitioners to feel a part of a greater whole and increase work motivation. The results obtained from the Spitzer motivation self assessment indicated that Noel scored high on affiliation. This was confirmed in his interview as he stated that he loved his colleagues and felt a sense of belonging because they have a very good relationship at work and he feels apart of the organization; his motivation style questionnaire confirmed that to relax he loves to hang out and talk with friends. Samantha's questionnaire did not capture her need for affiliation but it was captured from the interview. To Samantha the organization is like a "provision ground" where she feels that work is important and that the company and colleagues have become a part of her. In the interview she stated that "I often talk with my colleagues and discuss silly things as well as the job; we go out for lunch and to have fun", which shows a sense of job satisfaction and comradre. According to the motivation style questionnaire she likes to be recognized for being kind, thoughtful, and considerate to others.

\subsection{Need for Increased Job Satisfaction}

According to [1] job satisfaction is the pleasurable or positive emotional state resulting from the appraisal of one's job or job experience"; or it may be seen as a state of emotional gladness, resulting from the achievement of the goals that one get through performing his part of contribution inside an organization [6]. When asked if they are satisfied with their jobs, all three Participants stated that they received some amount of satisfaction from the job but the most satisfying encounters are those with their supervisors in a comfortable setting as well as those with customers who are warm, embracing and appreciate the work carried out by the employees. Abubakar et al. [7] states that a more inclusive and participatory styles of management also foster increased job satisfaction. Samantha supported this fact by stating that she is most satisfied on the job when her supervisor is able to give inputs and feedback where necessary, as well as provide her with guidance and materials to help speed up the work process, but this is not always the case.

Job satisfaction may also result from the work environment or when an employee is highly motivated whether intrinsically or extrinsically. When asked what aspect of the job gave them the most personal satisfaction, Noel stated that he gets a lot of satisfaction when he performs the job well and receives a bonus, or something to show for the work done. It is clear that job satisfaction relates to both intrinsic and extrinsic motivational factors which are desirable to get the job done. Laketa says "I get a lot of satisfaction when I am able to give ideas and it is used to make key decisions. I am satisfied when my work is completed on time with a great amount of accuracy". Noel says "I get a lot of satisfaction when the customers are happy and are appreciative about what I do, as well as when they praise me".

Job dissatisfaction is an indication of needed change feeling of displeasure or being unsatisfied. Although the three participants are satisfied with some aspect of the job, there are other areas that need improvement. When asked if there were aspects of the job they didn't like, Samantha states that "I hate when they give me task to complete without fully explaining to me how it should be done or the meaning behind it". "Tasks may be given outside my area of competency and I will have to do a lot of research which is time-consuming and at times I have to take incomplete work home- this should not be the case". This can lead to the worker becoming demotivated. Noel's source of dissatisfaction occurs when he has to report to the Director of Human Resources and get reports signed or budgets approved; he also stated that this makes his job very difficult.

\subsection{Need to Set More Appropriate Goals}

The Conner Motivation Style Assessment and the interviews conducted confirmed that both Samantha and Laketa have goal orientation as their primary motivation 
styles. They are persons who focus on tasks and the end results of those tasks are most important to them. Goal orientation advocates a focus on the end results instead of the tasks themselves and how those ends will affect either the person or the entire company. The researcher could classify Noel's primary style as goal orientation instead of learning orientation based on the interview results. In his interview he said that it's the end product of the process that is important to him and not the process itself. He said "Anything I set out to do I just want to achieve it at all cost, it's the end product of my objecttives that motivates me." It is said that people with strong goal orientation will be able to accurately judge the effects of reaching the goal as well as the ability to fulfill that particular goal with current resources and skills.

For all practitioners goals serve a directive function and as an energizing function; goals affect their persistence; and goals affect their actions indirectly by leading to the arousal, discovery, and/or use of task-relevant knowledge and strategies as is evident in the writings of [4].

\subsection{Need for Social Support}

Assistance and support are very important to Laketa, Samantha and Noel as it relates to the carrying out of their job functions within the organization. Getting the desired support will increase productivity, job satisfaction and by extension worker morale. Noel stated that "My co-workers are very supportive of me in my endeavors. They often give encouragement and tell of their own personal experiences and struggles in order to empathize".

\subsection{Need for Increased Self Efficacy}

Bandura (1986) viewed self-efficacy as the judgments of individuals regarding their ability to organize and perform daily works required to obtain successful performance [7]. All three participants are efficacious.

\subsection{Need for Autonomy and Empowerment}

The need for autonomy is innate in all human beings and a frustration of this need will lead to maladaptive behaveior. Self management and choice is important to all the participants with Noel having a greater need for autonomy. Performance-mastery approach is important in this case as to be autonomous within the organization the workers must show a sense of task performance and mastery before full task confidence is bestowed unto these workers. Noel stated that "I am driven by the task ahead and always want to do my best, trying to avoid failure. I don't need anyone to tell me what to do especially in my current job as I tend to use my own initiative where necessary and if allowed to do so". Laketa stated that "They allow me to make decisions, they give me some of the responsibilities and I like that. I feel motivated, respected and feel that I can be trusted." Samantha is keen on autonomy based on the interview results as she stated that she likes to do things on her own frequently.

\subsection{Intrinsic Motivation}

Noel is intrinsically motivated and stated in the interview that "Money by itself does not motivate me" "Self Determination Theory assumes that people are by nature active and self motivated, curious and interested, vital and eager to succeed because success itself is personally satisfying and rewarding", Deci et al. [8] "I am intrinsiccally motivated in the sense that I have the drive, passion, determination and will power to carry out certain functions within the work environment, as well as throughout my daily life". These strong statements obtained from the interview suggested that Noel is determined and intrinsically motivated.

\subsection{Extrinsic Motivation}

[8] states that extrinsic motivation involves engaging in an activity because it leads to some separate consequence. "I do tasks outside of my normal duties based on the fact that I may be compensated or somehow rewarded by getting overtime"; and "I might push myself during certain periods because I need the bonus near Christmas and during March" are arguments to suggest that Samantha and Laketa are motivated extrinsically.

\section{Possible Motivation Problems}

Based on the administration of the Questionnaires and the interviews conducted, it is clear that Laketa and Samantha have motivation problems while Noel is highly motivated. Laketa is high on ownership and low on competence, achievement, recognition and meaning. While it is desirable to have Laketa "owning" her objecttives and her work, thus being self-motivated to deliver and achieve, it may lead to problems in the long run. People such as Laketa who crave ownership may experience what Spritzer calls a "psychoanalytic notion of desire, with overtones of erotic possession". Laketa's work environments is always placing her under pressure to improve, this will put pressure on her desire for competence which is already low.

Samantha is low on competence according to the Spitzer motivation self assessment and scored in the yellow light category $(31-45)$, which means that she has some motivation problems. According to Oldham et al. [9] low task competence reduces intrinsic motivation, whereas attributions of personal causation and positive 
competence information enhance intrinsic motivation". This is further confirmed by the interview as she is more extrinsically than intrinsically motivated. Being extrinsically motivated has its disadvantages and Samantha may have problems with company loyalty, trust and job satisfaction. Samantha is always given tasks that are outside her area of competence as stated in the interview. Since she has a high desire for "meaning", this may lead to job dissatisfaction.

Noel has a high need for achievement which may be problematic in the future. His need for achievement is connected with a sense of success that can be quite short-lived, leading into almost obsessive repetition of achievement. While it is obvious that he is a good employee, his thirst to achieve at all cost and become highly recognized may cause Noel to behave inconsiderably to the needs of others. Noel is highly motivated and has a strong desire for power. Power at work is often aligned with position, expertise and personal charisma. The problem which exists is that he is not empowered enough on the job. Demotivators for Noel are the bureaucratic redtape and organizational politics that hinders his performance.

\section{Strategies to Deal with Motivation Problems}

- Employees must not indulge in self-limiting thinking, but think empowering, expansive thoughts. This will allow them to gain recognition

- Choose to be happy. Commit yourself to happiness and positive thinking because happy people are easily motivated. Never quit when you experience a setback or frustration. It is said that happiness leads to greater wellbeing, low absenteeism, and increased job satisfaction.

- Identify and eliminate demotivators

- Keep productively busy. In motivating organizations, employees should leave work feeling that they accomplished something worthwhile. Ask your employers to delegate responsibility and authority which is one of the fundamental ways to become motivated. With more responsibility and authority, employees will begin to act more like owners.

- Don't become passive within the organization, but carry out self-improvement activities as a means of improving your job.

- Make work fun and enjoyable, but balancing such enjoyment with increased productivity.

- Job rotations, job sharing, and temporary work assignments are some of the ways to add variety.

\section{Conclusion}

In order to heighten motivation at work, all three em- ployees must become more engaged, and dig in for their inner strength, drive and will-power to carry on. The most important aspect is to engage in work functions and activities which are most important for them and makes them happy, because well-being leads to greater organizational productivity.

\section{Future Research}

For future research, the sample size of future studies may be larger to determine how motivation in the work environment is viewed by gender differences. Further research could also look at the association of motivation styles, symptoms and the motivation desired on performance within the organization.

\section{REFERENCES}

[1] D. Moyniham and C. Pandey, "Finding Workable Levers over Work Motivation: Comparing Job Satisfaction, Job Involvement and Organizational Commitment," Administration and Society, Vol. 39, No. 4, 2007, p. 804.

[2] C. Pinder, "Work Motivation in Organizational Behaviour," 2nd Edition, Psychology Press, The University of British Columbia, 2008, p. 11.

[3] F. Mohsan, Khan and M. S, "Are Employee Motivation, Job Commitment, and Job Involvement Inter-related: Evidence for Banking Sector in Pakistan," International Journal of Business and Social Science, Vol. 2, No.17, 2011, p. 226

[4] G. Latham and G. Locke., "Building a Practically Useful Theory of Goal Setting and Task Motivation-A 35 Year Odyssey," American Psychological Association Inc. Vol. 57, No. 9, 2002, pp. 705-717.

[5] N. Allen and J. Meyer, "The Measurement and Antecedents of Affective, Continuance and Normative Commitment to the Organization," Journal of Occupational Psychology, Vol. 63, No. 1, 1990, pp. 1-18.

[6] I. Saleem, "Factors Affecting Job Satisfaction of Pakistani Bankers," Journal of Business Strategies, Vol. 6, No. 2, 2012, p. 251.

[7] M.-J. Abubakar, S. Bolaji and O. Luqman, "Job Satisfaction and Job Commitment: A Study of Quantity Surveyors in Nigerian Public Service," International Journal of Business and Management, Vol. 7, No. 5, 2012, pp. 179183.

[8] E. Deci and M. Ryan, "Facilitating Optimal Motivation and Psychological Well-Being Across Life's Domains," Canadian Psychology, Vol. 49, No. 1, 2009, pp. 14-15. http://dx.doi.org/10.1037/0708-5591.49.1.14

[9] G. Oldham and J. R. Hackman, "Not What It Was and Not What It Will Be, the Future of Job Design Research," Journal of Organizational Behaviour, Vol. 31, No. 2-3, 2012, p. 554. 